УДК 658.3.012.4

https://doi.org/10.33296/2707-0654-9(18)-13

\title{
ФЕДОРОВА ЮЛІЯ
}

кандидат економічних наук, доцент, доцент

кафедри економіки та менеджменту,

Українська інженерно-педагогічна академія, м.

Харків, Україна

ORCIDiD: https://orcid.org/0000-0002-9381-1229

\section{БАНТУШ ЛІЛІЯ}

магістрант, Українська інженерно-педагогічна академія, м. Харків, Україна

\section{УДОВІКОВА НАТАЛЯ}

магістрант, Українська інженерно-педагогічна академія, м. Харків, Україна

\section{КОУЧИНГ ЯК ЕФЕКТИВНИЙ ІНСТРУМЕНТ УПРАВЛІННЯ ПРОСКТНИМИ КОМАНДАМИ}

\begin{abstract}
Анотація. В умовах цифрової революції в економіці та менеджменті відбуваються активні зміни. Стабільні вертикальні бізнес структури замінюють гнучкі горизонтальні організаційні структури. Актуальними стають питання проєктного менеджменту. I вже не окремий співробітник, а команда стає базовою ланкою успішних проєктів. В цих умовах постає проблема удосконалення роботи проєктного менеджера.

В статті розглянуто методи підготовки та ефективного управління проєктними командами. Зазначено, що широкого розповсюдження набуває неформальна освіта у вигляді коротких бізнес-тренінгів та коуч-сесій. Розглянуто як змінюються функції керівника проєкту від традиційного керування до Agile-коучингу. Зазначено, що особливість Agile-коучингу в тому, що керівник безпосередньо бере участь у роботі. Він обирає демократичний стиль керівництва: питає поради у команди, дозволяє команді шукати власне рішення. В такий спосіб поліпшується внутрішня комунікація, зменшується напруга та кількість конфліктних ситуацій, покращується процес виконання проєктів. Мислення кожного учасника групи корелюється 3 цінностями методології гнучкого управління проєктами Agile.

Підкреслено, що рівень майстерності Agile-коуча залежить від його рівня емоційного інтелекту. Підвищення рівня емоційного інтелекту призводить до покращення здібностей коуча. Розглянутий інструмент має перспективи у сучасному проєктному менеджменті.

У статті зазначено, що застосування інноваційного гнучкого методу
\end{abstract}


Agile-коучу дозволить організовувати ефективну команду. Професійний Agileкоуч здатен мотивувати гнучкі організаційні структури до успішної реалізації проєктів, мотивувати до вивчення нового та допомагає впоратися 3 опором до нововведень. Саме в умовах невизначеності, багатозадачності, запровадження інноваційних заходів та постійний змін на зміну класичному управлінню в менеджменті має приходити Agile-коучинг управління проєктними командами.

Ключові слова:проєктні команди, управління проєктними командами, коучинг, Agile-коуч, компетентність, проєкт, навчання.

Вступ. В умовах структурних перетворень в галузі економіки та менеджменту, а саме зміні ресурсної економіки на економіку впливу, заміні вертикальних структур горизонтальними, в умовах збільшення уваги до стартапів, тощо , все більшу роль відіграє не стільки окремий працівник 3 високими KPI, скільки згуртована команда 3 емпативним лідером та учасниками 3 розвинутими гнучкими навичками. Проєктний менеджмент стає актуальним напрямком дослідження. А методи розвитку проєктної команди стають актуальною темою сьогодення. Це зумовило написання наукової статті на тему коучинга як ефективного інструменту розвитку та управління проєктною командою.

Аналіз останніх досліджень і публікацій. Проблематиці управління проєктними командами приділили увагу чисельні науковці. Зокрема, О.В. Зотов [1], В.Л. Дикань [2], I.I. Мазур [3], С.В. Панченко [4], В.М. Хобта [5] та ін. Питанням управління та підготовки персоналу присвятили дослідження закордонні науковці, зокрема: Е. Парслоу, Н. Томашек, Д. Уітмор, Сміт, Ф. Стоун, П. Хоукінс, Н., Я. Гибнер, Д. Ненашев, О. Самольянов, Р. Прайор та інші. Розвиток сучасних підходів до розвитку проєктних команд сприяє підвищенню інтересу до коучингу, як ефективного інструменту проєктного менеджменту.

Метою дослідження є визначення перспективних методів коучинга для розвитку проєктних команд.

Виклад основного матеріалу. Сьогодні менеджер 3 високим рівнем гнучких навиків $\epsilon$ цінним ресурсом для організації, тому що може монетизувати

\footnotetext{
(C) Українська інженерно-педагогічна академія

(C) ГО «Школа адаптивного управління сочіально-педагогічними системами»

(C) Федорова Ю., Бантуш Л., Удовікова Н.
} 
свої компетентності в капітал [6-9]. Так, менеджер, який вміє ефективно будувати комунікації та формує успішну команду збільшує шанси організації на успіх.

В умовах цифрової революції змінюється оточуюче середовище і виникає необхідність адаптування та управління змінами в різних аспектах людської діяльності. Ми спостерігаємо значні зміни в економічному середовищі, менеджменті та відповідно в освіті. Сьогодні освіта має формувати адаптивні, соціальні компетенції. Знання оновлюються так швидко, що нові навчальні програми потребують змін не один раз на рік, а значно частіше. В таких умовах одним iз ефективних видів навчання $є$ бізнес-тренінги та коучинги. Запровадження короткострокових програм бізнес-тренінгів надає можливість сучасним менеджерам, підприємцям, власниками бізнесу отримувати актуальні знання та підвищувати свої компетенції [8].

Команда є об’єднанням однодумців, які керуються спільною метою. Проєктна команда (команда проєкту) - сукупність працівників, які здійснюють функції управління проєктом і персоналом проєкту. Формуючи команду, керівник проєкту збирає разом групу людей, намагаючись об'єднати їх загальною метою та визначеними завданнями. Новизна, унікальність, ризик i швидкоплинність - риси притаманні проєкту, вони ж і визначають труднощі під час формування команди. Для того, щоб проєкт був успішним, згуртування людей повинно відбутися до того, як команда почне повноцінно працювати [10, c. 102]. Характеристика групи та команди, що полягає у визначенні особливостей, наведена у таблиці 1.

Сучасні тенденції розвитку управління кадрами характеризуються переорієнтацією на особистість працівника, зважаючи на те, що основною конкурентною перевагою суб'єкта господарювання є його співробітники. У такому разі основними аспектами, що потребують вивчення, є індивідуальні чинники мотивації працівників/членів команди та механізм побудови результативної системи мотивації. Застосування індивідуального (особистісного) підходу зумовлює необхідність аналізу, перегляду,

\footnotetext{
(C) Украӥнська інженерно-педагогічна академія

(с) ГО «Школа адаптивного управління сочіально-педагогічними системами»

(C) Федорова Ю., Бантуи Л., Удовікова Н.
} 
Електронне наукове фрахове видання «Адаптивне управління: теорія і практика»

вдосконалення та розвитку усіх складників управління кадрами, зокрема формування проєктної команди, що передбачає врахування індивідуальних особливостей характеру, темпераменту членів команди [11].

Таблиця 1

Основні відмінності між групою та командою [11]

\begin{tabular}{|c|c|c|c|}
\hline \multirow{2}{*}{ № } & \multirow{2}{*}{ Критерій } & \multicolumn{2}{|c|}{ Особливості } \\
\hline & & Група & Команда \\
\hline 1 & Лідерство & $\begin{array}{l}\text { Формальним лідером } є \\
\text { керівник / наявність } \\
\text { неформального лідера } \\
\text { в групі }\end{array}$ & $\begin{array}{l}\text { Формальним та неформальним } \\
\text { лідером є керівник }\end{array}$ \\
\hline 2 & $\begin{array}{l}\text { Головне функціональне } \\
\text { завдання керівника }\end{array}$ & $\begin{array}{l}\text { Контроль за діяльністю } \\
\text { підлеглих }\end{array}$ & $\begin{array}{l}\text { Створення середовища для } \\
\text { ефективної роботи }\end{array}$ \\
\hline 3 & Підпорядкованість & $\begin{array}{l}\text { Індивідуальна } \\
\text { підпорядкованість }\end{array}$ & $\begin{array}{l}\text { Індивідуальна } \\
\text { підпорядкованість } 3 \\
\text { елементами взаємної (керівник } \\
\text { є членом команди) }\end{array}$ \\
\hline 4 & Мета діяльності & $\begin{array}{l}\text { Вимушена орієнтація на мету } \\
\text { діяльності організації }\end{array}$ & $\begin{array}{l}\text { Сприйняття мети через призму } \\
\text { індивідуальних } \\
\text { цінностей/потреб }\end{array}$ \\
\hline 5 & Результат діяльності & $\begin{array}{l}\text { Продукти індивідуальної } \\
\text { праці }\end{array}$ & Продукт командної роботи \\
\hline 6 & Наради & $\begin{array}{l}\text { Необмежена кількість } 3 \\
\text { орієнтацією на процес } \\
\text { проведення }\end{array}$ & $\begin{array}{l}\text { Регламентована кількість } \\
\text { з орієнтацією на результативне } \\
\text { вирішення проблемних питань }\end{array}$ \\
\hline 7 & $\begin{array}{l}\text { Ефективність } \\
\text { діяльності }\end{array}$ & $\begin{array}{l}\text { Ефективність визначається } \\
\text { результатами кожного } \\
\text { окремого працівника }\end{array}$ & $\begin{array}{l}\text { Ефективність визначається } \\
\text { результатами командної } \\
\text { роботи }\end{array}$ \\
\hline 8 & Синергетичний ефект & Відсутній & Наявний \\
\hline 9 & Відповідальність & Індивідуальна & Колективна \\
\hline 10 & $\begin{array}{l}\text { Організаційна } \\
\text { структура }\end{array}$ & Жорстка & Гнучка \\
\hline 11 & $\begin{array}{l}\text { Функціональні } \\
\text { обов'язки }\end{array}$ & Стандартні & $\begin{array}{l}\text { Окремі функції, що притаманні } \\
\text { вищому керівнцтву }\end{array}$ \\
\hline
\end{tabular}

Управління проєктними командами - це складний процес, що передбачає контроль за діяльністю членів команди, забезпечення зворотного зв'язку, вирішення проблем та очолення змін для досягнення мети проєкту.

Безперервна освіта, відвідування бізнес-тренінгів надає конкурентні переваги активним менеджерам, які прагнуть професійного росту. Бізнестренінги допомагають підприємцям уникнути ряду помилок, ефективно (C) Українська інженерно-педагогічна академія

(С) ГО «Школа адаптивного управління соціально-педагогічними системами»

(C) Федорова Ю., Бантуш Л., Удовікова Н. 
використовувати час та запроваджувати ідеї. Мета бізнес-тренінгу як правило полягає у висвітленні новітніх знань щодо предмету бізнесу та формування сталих навичок в обраній сфері. Таким чином бізнес-тренінги відповідають актуальним запитам ринкової економіки i мають на меті вирішення конкретного завдання. Це групове навчання на одну тему. В процесі бізнестренінгу кожний учасник сам визначає для себе найбільш ефективні інструменти та методи, які відповідають його темпераменту, типу особистості, життєвій ситуації [8].

В результаті збільшення попиту на освітні, консалтингові послуги, та виникнення вимоги 3 урахуванням індивідуальних ситуацій, поширення набуває наступна більш клієнтоорієнований інструмент: коучинг. Коучинг передбачає вирішення конкретного завдання в реальній ситуації з урахуванням особистості замовника. Коучинг допомагає замовнику розробити власну «генеральну лінію», надихає, підтримує та кидає виклик. Ефективна сесія коучингу приносить бажання та енергію для подальшої роботи. Під коучингом будемо розуміти "процес, який сприяє реалізації навчання, розвитку, підвищення компетентності та удосконалення професійних навичок особи, що навчається [12,13].

Коучинг, як інноваційна форма консультування з’явився на початку 1980х років. Спочатку у спорті, а згодом і в бізнесі та політиці ця методика довела свою ефективність щодо досягнення цілей. Довгий час коучинг був привілею лише керівників вищого рівня.

Визначають три найбільш поширені форми коучингу: особистий, кар'єрний та бізнес-коучинг. Перший вид коучингу передбачає вирішення проблем особистого росту через зміну поведінки, вивчення власної системи цінностей, способів пристосування до дійсності, зміну їх на більш ефективні. Кар'єрний коучинг корисний у разі зміни професії, визначення шляхів кар'єрного росту або відкриття власної справи. I, нарешті, бізнес-коучинг передбачає консультування та супровід у питаннях запровадження корпоративного коучингу та розробки стандартів для внутрішніх коучів 
організації. Сьогодні спостерігається велика кількість спеціалістів з особистого коучингу, менша з кар'єрного коучингу та незначна у сфері бізнес-коучингу. Ми прогнозуємо збільшення в подальшому попиту не стільки на бізнестренінги, скільки на бізнес-коучинги в Україні [8].

У таблиці 2 наведено характеристику основних інструментів розвитку емоційного інтелекту в бізнесі.

Таблиця 2

Найбільш ефективні інструменти розвитку емоційного інтелекту в бізнесі

\begin{tabular}{|c|c|c|c|c|}
\hline Назва & $\begin{array}{c}\text { Форма } \\
\text { навчання }\end{array}$ & Мета & $\begin{array}{c}\text { Кількість } \\
\text { спеціалістів }\end{array}$ & $\begin{array}{c}\text { Стан } \\
\text { розвитку в } \\
\text { Україні } \\
\end{array}$ \\
\hline Бізнес-тренінг & $\begin{array}{l}\text { групове } \\
\text { навчання }\end{array}$ & $\begin{array}{l}\text { висвітлення новітніх } \\
\text { знань щодо предмету } \\
\text { тренінгу та формування } \\
\text { сталих навичок в обраній } \\
\text { сфері }\end{array}$ & велика & $\begin{array}{l}\text { набуває } \\
\text { поширення }\end{array}$ \\
\hline $\begin{array}{l}\text { Кар'єрний } \\
\text { коучинг }\end{array}$ & $\begin{array}{l}\text { особисте } \\
\text { навчання }\end{array}$ & $\begin{array}{l}\text { визначення шляхів } \\
\text { кар'єрного росту, } \\
\text { підтримка в разі зміни } \\
\text { професії або організації } \\
\text { власної справи }\end{array}$ & достатня & $\begin{array}{l}\text { має } \\
\text { перспективи }\end{array}$ \\
\hline $\begin{array}{l}\text { Управлінський } \\
\text { коучинг }\end{array}$ & $\begin{array}{l}\text { групове } \\
\text { навчання }\end{array}$ & $\begin{array}{l}\text { вирішення конкретних } \\
\text { завдань організації, беруть } \\
\text { участь менеджери вищої } \\
\text { та середньої ланки }\end{array}$ & достатня & $\begin{array}{l}\text { має } \\
\text { перспективи }\end{array}$ \\
\hline $\begin{array}{l}\text { Проєктний } \\
\text { коучинг }\end{array}$ & $\begin{array}{l}\text { групове } \\
\text { навчання }\end{array}$ & $\begin{array}{l}\text { Розробка портфелю } \\
\text { пропозицій щодо } \\
\text { вирішення конкретного } \\
\text { проєкту, беруть участь } \\
\text { учаснику проєкту }\end{array}$ & достатня & $\begin{array}{l}\text { має } \\
\text { перспективи }\end{array}$ \\
\hline Бізнес-коучинг & $\begin{array}{l}\text { групове } \\
\text { навчання }\end{array}$ & $\begin{array}{l}\text { консультування та } \\
\text { супровід у питаннях } \\
\text { запровадження } \\
\text { корпоративного коучингу } \\
\text { та розробки стандартів } \\
\text { для внутрішніх коучів } \\
\text { організації }\end{array}$ & $\begin{array}{l}\text { не вистачає, } \\
\text { запрошуються } \\
\text { закордонні } \\
\text { спеціалісти }\end{array}$ & $\begin{array}{l}\text { має } \\
\text { перспективи }\end{array}$ \\
\hline
\end{tabular}

В наведеній таблиці слід зазначити два найбільш ефективні та перспективні інструменти розвитку проєктного менеджменту: бізнес-тренінги та кар'єрні в бізнес-коучинги.

Проблемою $\epsilon$ те, що в умовах постійних змін вимог до проєкту 
організація згуртованої роботи команди $є$ непростим завданням. Одним 3 найбільш ефективних сучасних методів є методологія Agile.

Дослідники позначають критерії застосовності Agile, які забезпечать ефективність впровадження даної практики в діяльність організації:

1. Залучення замовника (можливість виділення на стороні бізнеспідрозділу співробітника, який буде відповідати за продукт і виступати в ролі його володаря, приймати підсумковий результат).

2. Команда і їі оточення (можливість створення крос-функціональних команд, що включають всі необхідні компетенції: аналітика, дизайнера, розробника, тестувальника, адміністратора автоматизованої системи чисельністю 5-9 осіб; залучення всіх учасників в процес (від виробництва до супроводу));

3. Система і їі оточення - архітектура системи повинна забезпечувати гнучке управління вимогами та безпечні часті впровадження [14].

Можна виділити наступні стилі Agile:

- навчання (чітке дотримання правил);

- коучинг ( перехід від дотримання правил до прийняття інших цінностей);

- консультування (самостійні рішення 3 дотриманням практик, цінностей).

Особливість Agile-коучингу в тому, що керівник безпосередньо бере участь у роботі. Він обирає демократичний стиль керівництва: питає поради у команди, дозволяє команді шукати власне рішення. В такий спосіб поліпшується внутрішня комунікація, зменшується напруга та кількість конфліктних ситуацій, покращується процес виконання проєктів. Мислення кожного учасника групи корелюється 3 цінностями методології гнучкого управління проєктами Agile. 
Історія розвитку проєкту к Agile-коучу представлено на рис. 1.

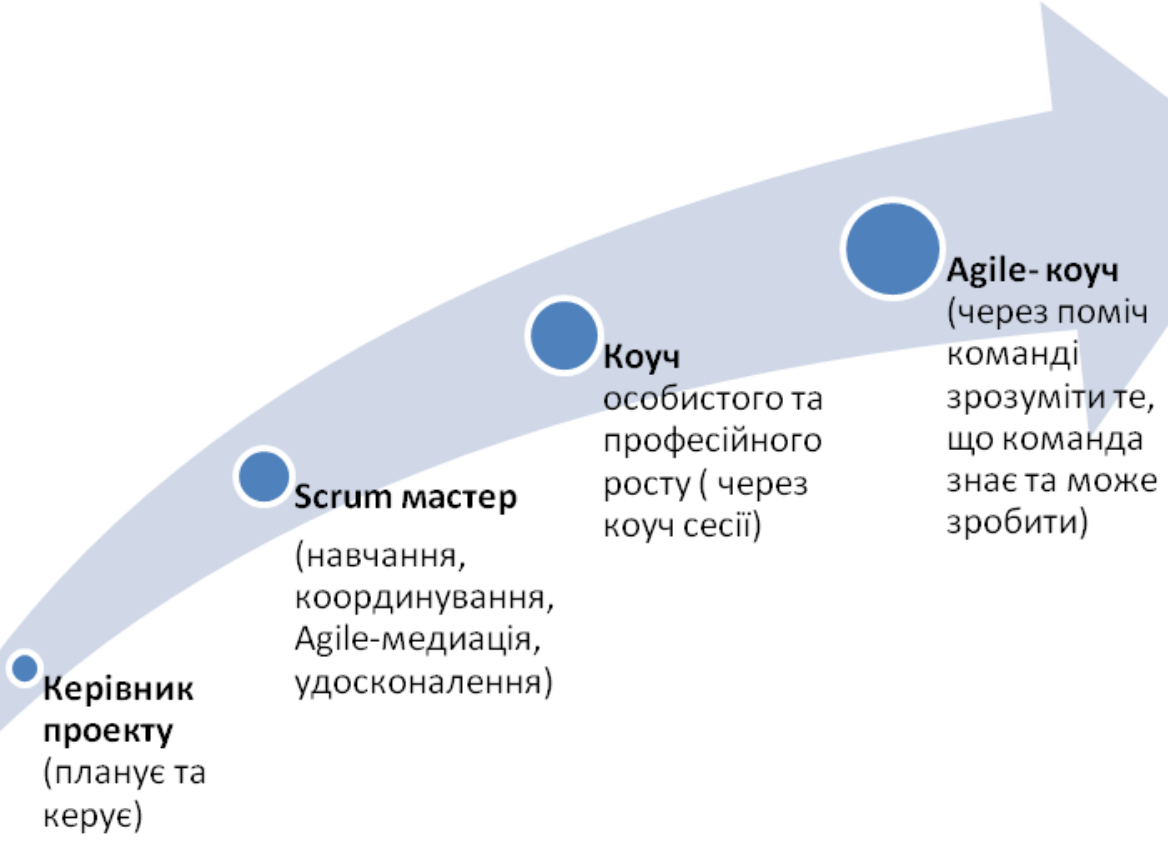

Рис. 1. Еволюція керівництва проєктами: від керівника проєкту до Agile-коуча

Л.Адкінс умовно поділяє Agile-коучей на «бульдозерів» (які допомагають зруйнувати перешкоди на шляху змін), «пастухів» (які надихають команду на вірний шлях agile-практик та принципів), «лідерівпастухів» (які віддано служать команді) та «стражів» якості виконання проєкту (слідкує за виконанням завдань кожного члену команди).

Функції Agile-коуча за Л.Адкинсом наведено у таблиці 3 [15].

Таблиця 3

\section{Функціонал Agile-коуча}

\begin{tabular}{|l|l|}
\hline \multicolumn{1}{|c|}{ Функції Керівника проєкту } & \multicolumn{1}{c|}{ Функції Agile-коуча } \\
\hline Планує та керує & Планує та сприяє виконанню \\
\hline $\begin{array}{l}\text { Використовує традиційні підходи у } \\
\text { виконанні завдань }\end{array}$ & $\begin{array}{l}\text { Концентрує увагу на бізнес-цінностях, вчить } \\
\text { команду бути ефективною }\end{array}$ \\
\hline Вимагає конкретні результати від команди & $\begin{array}{l}\text { Розвиває компетенції та сприяє розвитку } \\
\text { кожного члена команди }\end{array}$ \\
\hline Використовує перевірені часом стратегії & $\begin{array}{l}\text { Спонукає до креативу, надає можливість } \\
\text { бачити нові нетрадиційні рішення }\end{array}$ \\
\hline Здійснює контроль роботи команди & $\begin{array}{l}\text { Спостерігає за вільними рішеннями команди, } \\
\text { підтримує та бере відповідальність за } \\
\text { результати роботи команди }\end{array}$ \\
\hline
\end{tabular}

(C) Українська інженерно-педагогічна академія

(C) ГО «Школа адаптивного управління сочіально-педагогічними системами»

(C) Федорова Ю., Бантуи Л., Удовікова Н. 
Рівень майстерності Agile-коуча залежить від його рівня емоційного інтелекту. Підвищення рівня емоційного інтелекту призводить до покращення здібностей коуча.

Поняття «емоційний інтелект» передбачає єдине розуміння соціальнокогнітивних процесів, пов'язаних 3 накладенням емоцій на пізнавальну діяльність суб'єкта. Інтерес до розвитку емоційного інтелекту бере початок 3 кінця XIX століття та набуває активного теоретичного і експериментального дослідження у наші часи. Теорія емоційної компетентності в перші місяці своєї появи не сприймалася в бізнес-середовищі, оскільки у XX ст. вважалося, що емоції слід приховувати на робочому місці. Однак, американський дослідник Д. Гоулман обгрунтував думку, що саме керівники, які мають високий рівень емоційної компетентності приймають кращі рішення та діють ефективніше в критичних ситуаціях та в управлінні людським капіталом організації. Саме емоційній інтелект пояснює когнітивні здібності та особливості людини, які дозволяють бути їй успішній в комунікаційних процесах сучасного бізнессередовища [8].

Л.Адкінс виокремлює такі ролі Agile-коуча [15]:

1. Наставник. Agile-коуч займається коучингом особистісного зростання, щоб допомогти людині досягти мети. Agile-коуч ділиться власним досвідом та ідеями, допомагаючи правильно застосовувати Agile.

2. Фасилітатор. Члени команди знаходяться в постійному спілкуванні, як формальному, так і неформальному. Фасилітація націлена на спостереження коуча за учасниками команди та поліпшення взаємодії учасників команди.

3. Учитель. Agile-коучі вчать найпростішим і дієвим Agile-методам.

4. Навігатор конфлікту. Agile-коуч допомагає учасникам команди визнати конфлікт і вибрати правильний спосіб його вирішення.

5. Диригент спільної роботи. Спільна робота - це величезний крок вперед, особливо в порівнянні з тими часами, коли Agile-підходу ще не існувала. Мета Agile-коуча - сформувати самостійну команду.

Висновки. Таким чином, у статті зосереджено увагу на такому гнучкому 
методі коучингу, як Agile-коучинг. Автор вважає, що розглянутий інструмент має перспективи у розвитку проєктного менеджменту. Застосування цього методу дозволить керівнику, який буде виступати Agile-коучем організовувати діяльність ефективної команди. Професійний Agile-коуч здатен мотивувати гнучкі організаційні структури до успішної реалізації проєктів, мотивувати до вивчення нового та допомагає впоратися 3 опором. Agile-коуч має постійно підвищувати свій емоційний інтелект, бо це запорука ефективних комунікацій у команді. Саме в умовах невизначеності, багатозадачності, запровадження інноваційних заходів та постійний змін на зміну класичному управлінню менеджера має приходити команда на чолі з Agile-коучем.

Перспективи дослідження. Подальшим напрямом дослідження є:

1) розробка прогресивних напрямів Agile-коучингу для проєктної команди;

2) розробка коуч-сесій для мотивування працівників приймати креативні рішення.

\section{Використана література}

1. Зотов О.В. Проєкт, управління проєктом: основні поняття, суб’єкти державного управління. Державне управління: удосконалення та розвиток: електронне наукове фахове видання. $2010 . \quad$ № 8. URL:http://www.dy.nayka.com.ua/?op=1\&z=171.

2. Дикань В.Л. Етичні основи бізнесу: підручник. Харків: УкрДАЗТ, 2012. 316.

3. Мазур И.И. Управление проєктами: учеб. пос. М.: Омега-Л, 2014. 664.

4. Панченко С.В. Управління бізнесом: підручник. Харків: УкрДУЗТ, 2016. 312 c.

5. Хобта В.М. Активізація і підвищення ефективності інвестиційних процесів на підприємствах: монографія. НАН України. Ін-т економіки пром-ті. МОН України. ДонНТУ. Донецьк, 2013. 343 с.

6. Федорова Ю.В. Глобализация: экономический аспект. Вісник Хмельницького національного університету. Економічні науки. 2017. № 1. С. 177-181. - URL: http://nbuv.gov.ua/UJRN/Vchnu_ekon_2017_1_38.

7. Федорова Ю., Бабенко К., Малихіна Я., Ярмош О., Малихіна В. Проблеми підготовки керівників у сфері публічного управління та адміністрування в умовах цифрової економіки. Фінансово-кредитна діяльність: проблеми теорії та практики. 2019. Том 1, № 3 (30). C.501-509. - URL: DOI: https://doi.org/10.18371/fcaptp.v3i30.179926.

\footnotetext{
(C) Украӥнська інженерно-педагогічна академія

(с) ГО «Школа адаптивного управління сочіально-педагогічними системами»

(C) Федорова Ю., Бантуш Л., Удовікова Н.
} 
8. Федорова Ю.В. Емоційний інтелект у бізнесі: інструменти та методи розвитку. Електронне наукове фахове видання «Адаптивне управління: теорія $i$ практика». 2019. Випуск 6 (12). DOI https://doi.org/10.33296/2707-0654-6(12)$\underline{01}$.

9. Федорова Ю.В. Рецесія неоліберальної глобалізації як зовнішній виклик національній інноваційній політиці Електронне наукове видання «Адаптивне управління: теорія і практика» Серія Економіка. 2018. № 5(10). URL: http://am.eor.by/index.php/gallery/129-vipusk-5-10-2018.

10. Романовський О. Феномен підприємництва в університетах світу: монографія. Вінниця: Нова Книга, 2012. 504с.

11. Занора В. О. Управління кадрами: теоретичні аспекти формування проєктної команди . Науковий вісник Херсонського державного університету. Сер. : Економічні науки.2018. Вип. 30 (1). С. 87-90. - URL: http://nbuv.gov.ua/UJRN/Nvkhdu_en_2018_30\%281\%29_22.

12. Bodepudi M. Roles and Responsibilities of Project Manager \& Project Management Team, 2018. URL: https://www.greycampus.com/blog/projectmanagement/roles-and-responsibilities-of-project-manager-and-project-managementteam.

13. Чуланова О.Л. Коуч-лидерство как инструмент формирования softskills управленческого персонала современных организаций. Экономика предприятий. $2018 . \quad$ T. 4 , № $4 . \quad-\quad$ URL: https://riorpub.com/ru/nauka/article/20665/view.

14. Долженко Р. А. Использование Agile-подхода в практике бизнеса. - URL: https://alprex.ru/stati/ispolzovanie-agile-podhoda-v-praktike-biznesa.

15. Адкинс Л. Коучинг Agile-команд. Руководство для Scrum-мастеров, Agile-коучей и руководителей проєктов в переходный период, пер. с англ. C. Пасерба. М. : Манн, Иванов и Фербер, 2017. 416 с.

\section{References}

1. Zotov O.V. (2010) Proekt, upravlinnia proektom: osnovni poniattia, subiekty derzhavnoho upravlinnia [Project, project management: basic concepts, subjects of public administration]. Derzhavne upravlinnia: udoskonalennia ta rozvytok: elektronne naukove fakhove vydannia . №8. Retrieved from: http://www.dy.nayka.com.ua/?op=1\&z=171 [in Ukrainian].

2. Dykan V.L. (2012) Etychni osnovy biznesu [Ethical foundations of business]: pidruchnyk. Kharkiv: UkrDAZT, 316. [in Ukrainian].

3. Мазур, И.И. Управление проєктами: учеб. пос. М.: Омега-Л, 2014. 664. [in Ukrainian].

4. Panchenko S.V. (2016) Upravlinnia biznesom [Business management]: pidruchnyk .Kharkiv: UkrDUZT. 312 c. [in Ukrainian].

5. Khobta V.M. (2013) Aktyvizatsiia i pidvyshchennia efektyvnosti investytsiinykh protsesiv na pidpryiemstvakh [Activation and increase of efficiency 
of investment processes at the enterprises]: monohrafiia. NAN Ukrainy. In-t ekonomiky prom-ti. MON Ukrainy. DonNTU. Donetsk. 343 c. [in Ukrainian].

6. Fedorova Y. (2017) Globalizatsiya: ekonomicheskiy aspekt.[Globalization: The Economic Aspect] Visnik Hmelnitskogo natsIonalnogo unIversitetu. EkonomIchnI nauki.1. 177-181. Retrieved from: http://nbuv.gov.ua/UJRN/Vchnu_ekon_2017_1_38[in Russian].

7.Fedorova Y., Babenko K., Malykhina Y., Yarmosh O., Malykhina V. (2019) Problemy pidhotovky kerivnykiv $u$ sferi publichnoho upravlinnia ta administruvannia $\mathrm{v}$ umovakh tsyfrovoi ekonomiky. [Problems of preparation of curriculum in the sphere of public administration and administration in the minds of the digital economy]Finansovo-kredytna diialnist: problemy teorii ta praktyky.2019. № 3 (30). 501-509. 3 Retrieved DOI: https://doi.org/10.18371/fcaptp.v3i30.179926[in Ukrainian].

8. Fedorova Y. (2019) Emotsiinyi intelekt u biznesi: instrumenty ta metody rozvytku. [Emotional intelligence in business: tools and methods of development] Elektronne naukove fakhove vydannia "Adaptyvne upravlinnia: teoriia i praktyka» Vypusk 6 (12).Retrieved from: DOI https://doi.org/10.33296/2707-0654-6(12)-01 [in Ukrainian].

9. Fedorova Y. (2018) Retsesiia neoliberalnoi hlobalizatsii yak zovnishnii vyklyk natsionalnii innovatsiinii politytsi [The recession of neoliberal globalization as an external challenge to national innovation policy] Elektronne naukove vydannia "Adaptyvne upravlinnia: teoriia i praktyka" Seriia Ekonomika,5(10). Retrieved from: http://am.eor.by/index.php/gallery/129-vipusk-5-10-2018[in Ukrainian].

10. Romanovskyi O. (2012) Fenomen pidpryiemnytstva v universytetakh svitu: monohrafiia [The phenomenon of entrepreneurship in the world's universities]. Vinnytsia: Nova Knyha, 504. [in Ukrainian].

11.Zanora V.O. (2018) Upravlinnia kadramy: teoretychni aspekty formuvannia proektnoi komandy [Personnel management: theoretical aspects of project team formation]. Naukovyi visnyk Khersonskoho derzhavnoho universytetu. Ser.: Ekonomichni nauky. 30(1). 87-90. Retrieved from: http://nbuv.gov.ua/UJRN/Nvkhdu_en_2018_30\%281\%29_22 [in Ukrainian].

12. Bodepudi M. (2018) Roles and Responsibilities of Project Manager \& Project Management Team, 2018. Retrieved from: https://www.greycampus.com/blog/project-management/roles-and- responsibilitiesof-project-manager-and-project-management-team.

13. Chulanova O.L. (2018). Kouch-liderstvo kak instrument formirovaniya soft skills upravlencheskogo personala sovremennyih organizatsiy. [Coach leadership as a tool for the formation of soft skills of managerial staff of modern organizations] Ekonomika predpriyatiy.4,4. Retrieved from: https://riorpub.com/ru/nauka/article/20665/view [in Russian].

14. Dolzhenko R. A. (2015) Yspolzovanye Agile-podkhoda v praktyke byznesa [Using the Agile approach in business practice]. Retrieved from: https://alprex.ru/ stati/ispolzovanie-agile-podhoda-v-praktike-biznesa [in Ukrainian].

15. Adkins L. (2017) Kouching Agile-komand. Rukovodstvo dlya Scrum- 
masterov, Agile-kouchey i rukovoditeley proektov v perehodnyiy period [Agile team coaching. A Guide for Scrum Masters, Agile Coaches, and Project Leaders in Transition] , per. s angl. S. Paserba. M. : Mann, Ivanov i Ferber. 416. [in Russian].

\section{ФЕДОРОВА ЮЛИЯ}

кандидат экономических наук, доцент кафедры экономики и менеджмента, Украинская инженерно-педагогическая академия, г. Харьков, Украина

\section{БАНТУШ ЛИЛИЯ}

магистрант, Украинская инженерно-педагогическая академия, г. Харьков, Украина

\section{УДОВИКОВА НАТАЛЬЯ}

магистрант, Украинская инженерно-педагогическая академия, г. Харьков, Украина

\section{КОУЧИНГ КАК ЭФФЕКТИВНЫЙ ИНСТРУМЕНТ УПРАВЛЕНИЯ ПРОЕКТНОЙ КОМАНДОЙ}

Аннотация. В условиях цифровой революции в экономике и менеджменте происходят активные изменения. Стабильные вертикальные бизнес структуры заменяют гибкие горизонтальные организационные структуры. Актуальными становятся вопросы проєктного менеджмента. И уже не отдельный сотрудник, а команда становится базовым звеном успешных проєктов. В этих условиях возникает проблема совершенствования работы проєктного менеджера.

В статье рассмотрены методы подготовки и эффективного управления проєктными командами. Отмечено, что широкое распространение приобретает неформальное образование в виде коротких бизнес-тренингов и коуч-сессий. Рассмотрены как изменяются функции руководителя проєкта от традиционного управления в Agile-коучинга. Отмечено, что особенность Agile-коучинга в том, что руководитель непосредственно участвует в работе. Он выбирает демократический стиль руководства: спрашивает совета у команды, позволяет команде искать собственное решение. Таким образом улучшается внутренняя коммуникация, уменьшается напряжение и количество конфликтных ситуаций, улучшается процесс выполнения проєктов. Мышление каждого участника группы коррелирует с ценностями методологии гибкого управления проєктами Agile.

Подчеркнуто, что уровень мастерства Agile-коуча зависит от его уровня эмоционального интеллекта. Повышение уровня эмоционального интеллекта приводит к улучшению способностей коуча. Рассмотрен инструмент имеет перспективы в современном проєктном менеджменте.

В статье указано, что применение инновационного гибкого метода Agileкоучу позволит организовывать эффективную команду. Профессиональный

\footnotetext{
(C) Украӥнська інженерно-педагогічна академія

(C) ГО «Школа адаптивного управління сочіально-педагогічними системами»

(C) Федорова Ю., Бантуш Л., Удовікова Н.
} 
Agile-коуч способен мотивировать гибкие организационные структуры к успешной реализации проєктов, мотивировать к изучению нового и помогает справиться с сопротивлением к нововведениям. Именно в условиях неопределенности, многозадачности, внедрение инновационных мероприятий и постоянный изменений на смену классическому управлению в менеджменте должен приходить Agile-коучинг управления проєктными командами.

Ключевые слова: проєктные команды, управление проєктными командами, коучинг, Agile-коуч, компетентность, проєкт, обучение.

\title{
FEDOROVA YULIIA
}

Ph.D in Economic Sciences, Ukrainian Engineering Pedagogics Academy, Kharkiv, Ukraine

\section{BANTUSH LILIIA}

master, Ukrainian Engineering Pedagogics Academy, Kharkiv, Ukraine

\section{UDOVIKOVA NATALIA}

master, Ukrainian Engineering Pedagogics Academy, Kharkiv, Ukraine

\section{COACHING AS AN EFFECTIVE TOOL OF PROJECT TEAM MANAGEMENT}

\begin{abstract}
In the conditions of the digital revolution in the economy and management there are active changes. Stable vertical business structures replace flexible horizontal organizational structures. Issues of project management are becoming relevant. And no longer an individual employee, but a team becomes the basic link of successful projects. In these conditions, there is a problem of improving the work of the project manager.
\end{abstract}

The article considers the methods of preparation and effective management of project teams. It is noted that non-formal education in the form of short business trainings and coaching sessions is becoming widespread. It is considered how the functions of the project manager change from traditional management to Agilecoaching. It is noted that the peculiarity of Agile-coaching is that the leader is directly involved in the work. He chooses a democratic leadership style: he asks the team for advice, allows the team to find their own solution. In this way, internal communication is improved, tension and the number of conflict situations are reduced, and the project implementation process is improved. The thinking of each group member correlates with the values of Agile's flexible project management methodology.

It is emphasized that the skill level of an Agile coach depends on his level of emotional intelligence. Increasing the level of emotional intelligence improves the coach's abilities. The considered tool has prospects in modern project management.

The article states that the use of an innovative flexible method of Agile-coach will allow you to organize an effective team. A professional Agile coach is able to motivate flexible organizational structures to successfully implement projects, motivate them to learn new things and help them cope with resistance to innovation. It is in conditions of uncertainty, multitasking, the introduction of innovative measures and constant changes to replace the classic management in management should come Agile-coaching project management.

Keywords: project teams, project team management, coaching, Agile coach, competence, project, training.

\footnotetext{
(C) Украӥнська інженерно-педагогічна академія

(C) ГО «Школа адаптивного управління сочіально-педагогічними системами»

(C) Федорова Ю., Бантуи Л., Удовікова Н.
} 